\title{
Identify the Oil Seepage in Plantungan Geothermal Manifestation, Kendal Using HVSR Method
}

\author{
Fatma $^{1, *}$, Gatot Yuliyanto $^{2}$, Udi Harmoko ${ }^{2}$ \\ ${ }^{1}$ Master Program of Energy, School of Post Graduate Studies, Diponegoro University, Semarang - Indonesia \\ ${ }^{2}$ Department of Physics, Faculty of Science and Mathematics, Diponegoro University, Semarang - Indonesia
}

\begin{abstract}
The presence of oil seepage to the surface indicates that at least an active petroleum system is present subsurface. Oil seepage that occurred in Plantungan, Kendal, Central Java, has been known since 1971 and still produces seepage until today. On the research area, three oil seepages point were found. Plantungan region is located in East Serayu Zone underlain by volcanic area, and based on the Geology Map, the research area is located in Banjarnegara-Pekalongan Sheet. To understand the geology condition of the research area, a subsurface mapping is needed, even though the mapping does not provide the depth of bedrock and reservoir, data recording using HVSR (Horizontal to Vertical Spectrum Ratio) method that has been done in 18 points is able to provide $V_{p}$ and density profile to understand the distribution of oil seepage. The oil seepage is most prominent close to SB09 location, however the result from crossplot found that the value of highest $\mathrm{V}_{\mathrm{p}} \times$ density is on $\mathrm{SB} 12 \mathrm{~A}$ with $4,306,197 \mathrm{~kg} / \mathrm{m}^{2} \mathrm{~s}$, and lowest $\mathrm{V}_{\mathrm{p}} \times$ density in on SB17A with $302,305.3 \mathrm{~kg} / \mathrm{m}^{2} \mathrm{~s}$.
\end{abstract}

Keywords: Oil Seepage; Oil Seepage in Volcanic area; Oil Seeps in Geothermal Manifestation; Acoustic Impedance; HVSR Method; Spectra Ratio Method

\section{Introduction}

Oil seepage is a presence of oil at the surface which migrated from the high pressure condition to low pressure through rocks fracture [1]. Seepage has various component variables, such as oil, gas, liquid bitumen, asphalt and tar [2]. According to Zheng et al. (2018), types of seepage are divided into two, which are macroseepage; oil, gas, volcanic mud, and bitumen. While micro-seepage is the released emission.

Petroleum oil itself, both offshore and onshore, is predicted to have more than 1,150 seepage points in 84 countries in the world, including Indonesia [2]. In Java Island itself, oil and gas seepage is focused on three main area, which are Banten, Majalengka, and East Serayu. These three area are also located in volcanic area, however, based on the petroleum geology, all of them have a different petroleum system [3].

Administratively, the research area is located between two villages, which are Sangubanyu Village, Bawang District, Batang City and Tirtomulyo Village, Plantungan District, Kedal City. Geographically, the research area is located between $7^{\circ} 5^{\prime} 51.46^{\prime \prime S}-7^{\circ} 6^{\prime} 4.55^{\prime \prime S}$ and $109^{\circ} 57^{\prime} 40.05^{\prime \prime} \mathrm{E}-109^{\circ} 57^{\prime} 55.43^{\prime \prime} \mathrm{E}$. If seen from the physiography of Central Java, the research area is included in the East Serayu Zone with many volcanic mountains surrounding the site (Fig 1)

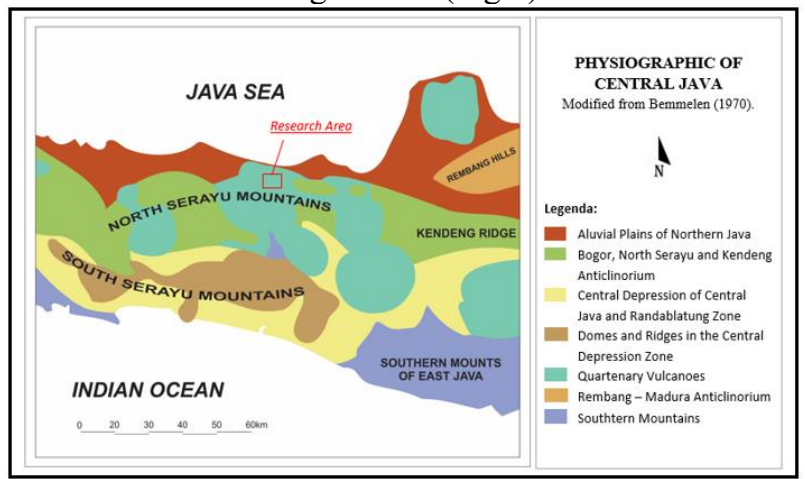

Fig. 1. Physiography Map of Central.

Oil seepage that happened in Plantungan District, Kendal, has been known before in a study done by Truesdell (1971). Other than oil seepage on the research area, there are also some hot pool point which is a characteristic of geothermal source manifestation, but will not discuss it in detail.

The conceptual model of a geothermal site is based on the geological information, both from the mapping of the surface to subsurface analysis, geophysics survey result, geochemical, to sampling of reservoir liquid from the

\footnotetext{
* Corresponding author: fatma.arfan $@$ student.undip.ac.id
} 
well, temperature information and pressure condition based on well logging result [5]. Some of the results from that method can become a parameter that directly refer to geology activity [6]. There are various methods for geophysics that are usually done, such as geoelectricity, seismic, gravity, magnetic method. In this paper author used HVSR (Horizontal to Vertical Spectral Ratio) seismic method.

\section{Horizontral to Vertical Spectral Ratio (HVSR) Method}

The earth surface is always moving in seismic frequency even with or without earthquake movement. The constant vibration on the earth surface is called microseism or microtremors or generally termed as microtremor [7]. Microtremor is a vibration that has very small amplitude of approximately 0.1 to $1.0 \mu$ and speed of vibration of approximately $0.001 \mathrm{~cm} / \mathrm{s}$ to $0.01 \mathrm{~cm} / \mathrm{s}$ [8].

The earth has elastic wave that propagates inside earth and on the surface, this is called seismic wave, this depends on the elasticity of the rocks. Body wave consists of $\mathrm{P}$ and $\mathrm{S}$ wave. $\mathrm{P}$ wave is a longitudinal wave that has the same direction with particles' movement to the propagated wave, while $\mathrm{S}$ wave is one of the wave propagations that has particles' movement perpendicular to the propagation. Surface wave is a complex wave with low frequency and high amplitude. This wave is divided into Love and Rayleigh wave. Love wave is a surface wave that the particles' are vibrating through the propagation direction. Rayleigh wave is a type of wave that has linear particles' movement direction to the direction of propagation and plane [9]. Moreover, $\mathrm{P}$ and $\mathrm{S}$ wave are used to determine the value of $\mathrm{V}_{\mathrm{p}}$ and $\mathrm{V}_{\mathrm{p}} / \mathrm{V}_{\mathrm{s}}[10]$.

HVSR method is one of the method that generally used for microtremor three components to identify the depth of bedrock. Moreover, this method can be used to determine the dominant resonance frequency (f0) and peak point of HVSR (A) which show the sediment's dynamic characteristic. If both values are known, then seismic susceptibility index in $\mathrm{kg}$ can be calculated. Parameters used in HVSR method are amplification and natural frequency, where these two factors are related to underground physical parameters to geologically understand the characteristics of research area [11]. This method was introduced by a researcher named Nakamura on 1989 with the principle of calculating the spectrum ration between total component of horizontal and vertical resultant [12].

In the beginning, this method is used to predict resonance frequency and amplification factor of local geology from microseisms data. However, in its development, this method is able to determine ground susceptibility index, rock susceptibility index, and to map sediment thickness qualitatively [13]

The equation of this HVSR method is as follows:

$$
R(f)=\frac{\sqrt{H e w^{2}(\mathrm{f})-H n s^{2}(\mathrm{f})}}{\operatorname{Vud}(\mathrm{f})}
$$

Where:

$\mathrm{R}(\mathrm{f}) \quad=$ HVSR Rasio Spectrum

Hew (f) $=$ Horizontal Component Spectrum E-W

Hns (f) $=$ Horizontal Component Spectrum N-S.

Vud (f) = Vertical Component Spectrum.

Whereas to find the thickness of the sediment layer $(\mathrm{H})$ the equation is used:

$$
f 0=\frac{V_{s}}{4 H}
$$

Where f0 for Dominant frequency $(\mathrm{Hz}), \mathrm{V}_{\mathrm{s}}$ for Wave propagation in the sediment layer $(\mathrm{m} / \mathrm{s})$, and $H$ for Thickness of sediment layer (m) [12].

Moreover, HVSR method can use to find $V_{p} \times \rho$ value, it is an acoustic impedance value. Acoustic impedance value is used to see rock compactness [14]. The equation of this can be described as bellow:

$$
Z=V_{p} \times \rho
$$

With $\mathrm{Z}=$ Acoustic Impedance $\left(\mathrm{kg} / \mathrm{m}^{2} \mathrm{~s}\right), \mathrm{V}_{\mathrm{p}}=$ Propagation of wave P $(\mathrm{m} / \mathrm{s}), \rho=$ Density of the formation $\left(\mathrm{kg} / \mathrm{m}^{2}\right)$.

\section{Methodology}

Past observation was done by Truesdell in 1971, this is the basis of the continuation observation done in this research. The observation is done directly on site and three oil seepage point were found to be close to each other (Fig 5). The presence of oil to the surface that happens until now is an evidence that there is still an active petroleum system in subsurface [15]. Oil seepage that present to the surface of research area has the characteristics of yellowish black and has distinct smell of crude oil (Fig 2).

Equipment used for data acquisition are seismometer with three components, data logger DI 170, compass, and laptop to process data that has been collected on site. Data collection was done in an area of $560 \mathrm{~m} \times 400 \mathrm{~m}$ with 18 points at first and 4 additional points around the seepages they are SB09A, SB12A, SB13A, and SB17A (Fig 3 and $4)$. Components in seismometer consist of three parts, which are vertical data component (up and town) and two horizontal data component; South-North and East-West [9]. Data was processed with GEOPSY software to measure spectral ratio of HVSR and SURFER12 for contour mapping. 


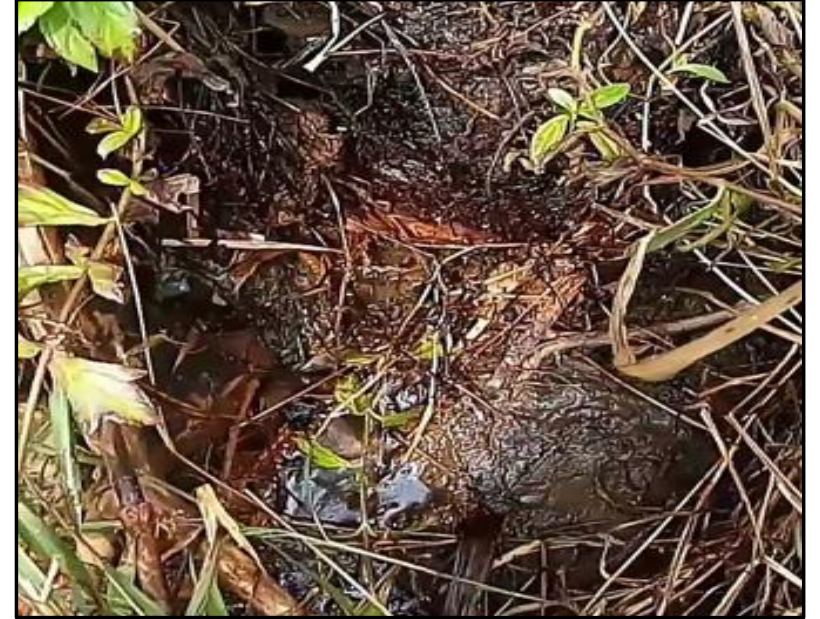

Fig. 2. One of Oil Seepage in Research Area.

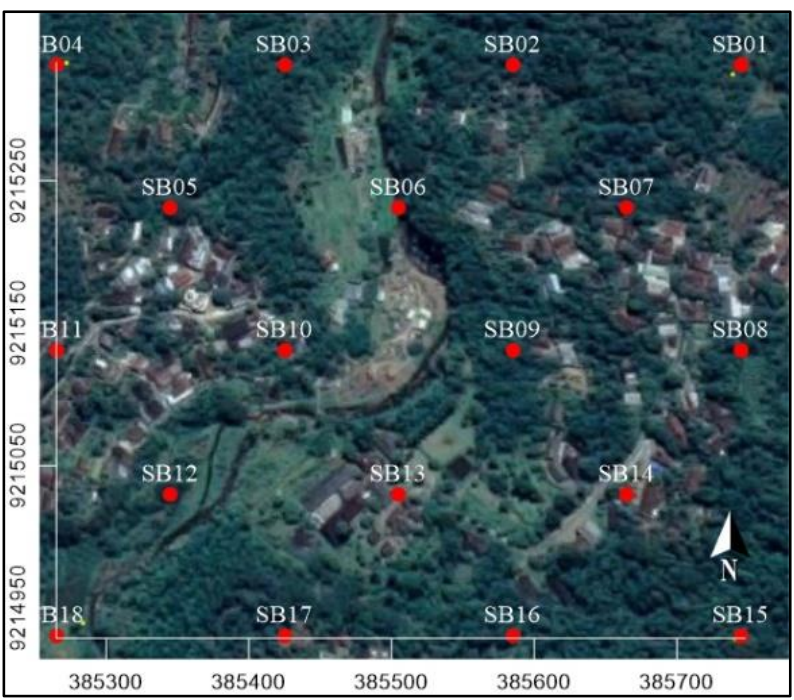

Fig. 3. Map of Data Collection Planning in 18 Points without 4 additional points.

\section{Result and Discussion}

The collected data was then processed using GEOPSY software and dominant frequency value (fo) trough HVSR curve as Fig 4 and was obtained as shown in Table 1.

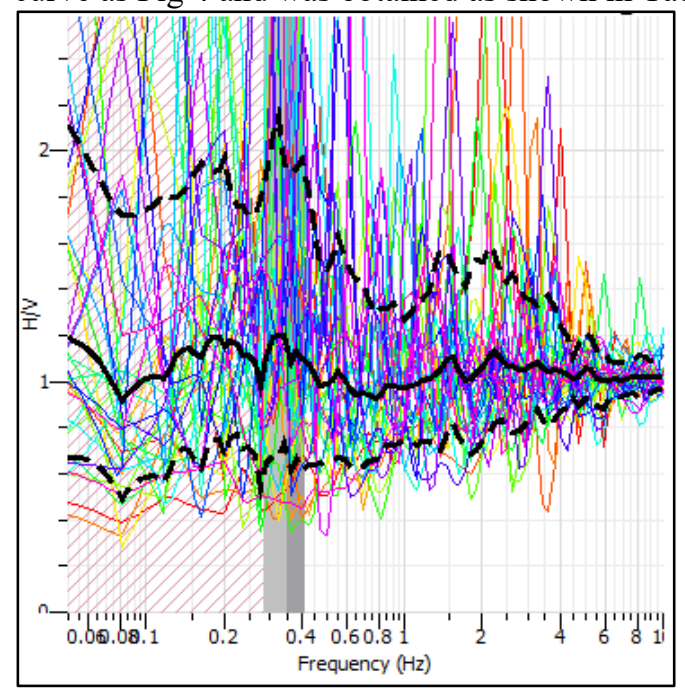

Fig. 4. HVSR curve at Point SB13 with highest dominant frequency value (f0).

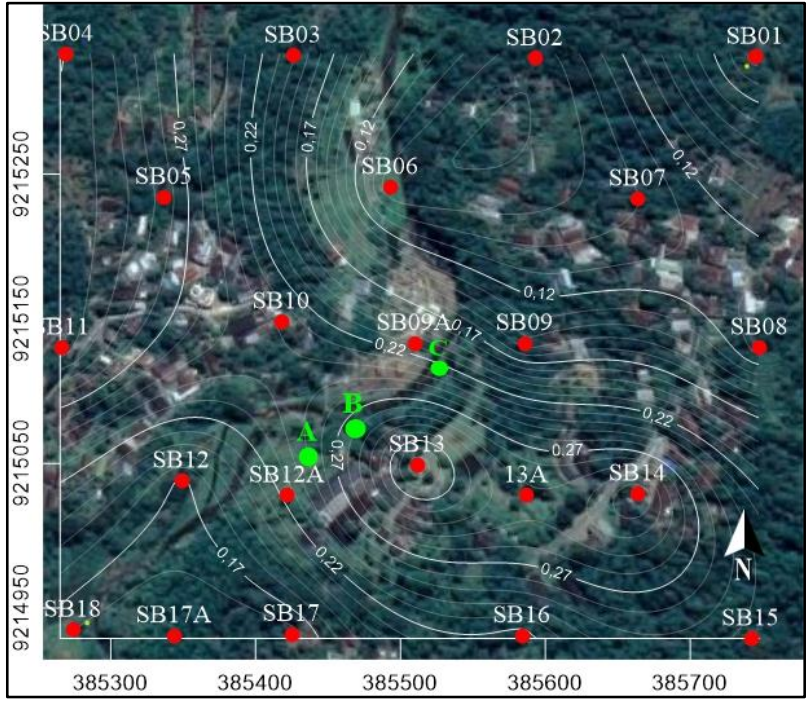

Fig. 5. Point $A, B$ and $C$ are the points where oil seepage to the surface is found. The most visible seepage is at point $C$.

Table 1. Result of fo Value Analysis.

\begin{tabular}{|c|c|c|c|c|}
\hline \multirow{2}{*}{$\begin{array}{c}\text { Point } \\
\text { Name }\end{array}$} & \multicolumn{2}{|c|}{ Coordinate } & $\begin{array}{c}\text { Dominant } \\
\text { Frequency }\end{array}$ & $\begin{array}{c}\text { Sediment } \\
\text { Thickness } \\
\text { (m) }\end{array}$ \\
\hline SB01 & 385745 & 9215331 & 0.195216 & 514.46 \\
\hline SB02 & 385593 & 9215330 & 0.080938 & $1,240.82$ \\
\hline SB03 & 385426 & 9215332 & 0.201886 & 497.46 \\
\hline SB04 & 385269 & 9215333 & 0.319821 & 314.02 \\
\hline SB05 & 385337 & 9215234 & 0.286295 & 350.79 \\
\hline SB06 & 385493 & 9215241 & 0.080614 & $1,245.81$ \\
\hline SB07 & 385664 & 9215233 & 0.099419 & $1,010.17$ \\
\hline SB08 & 385748 & 9215130 & 0.103424 & 971.05 \\
\hline SB09 & 385586 & 9215133 & 0.143077 & 701.93 \\
\hline SB09A & 385510 & 9215133 & 0.274879 & 365.36 \\
\hline SB10 & 385418 & 9215148 & 0.23836 & 421.34 \\
\hline SB11 & 385266 & 9215130 & 0.316759 & 317.05 \\
\hline SB12 & 385349 & 9215038 & 0.167293 & 600.32 \\
\hline SB12A & 385418 & 9215148 & 0.23836 & 461.66 \\
\hline SB13 & 385512 & 9215049 & 0.350805 & 286.28 \\
\hline SB13A & 385357 & 9215137 & 0.22065 & 289.43 \\
\hline SB14 & 385664 & 9215029 & 0.322214 & 311.69 \\
\hline SB15 & 385742 & 9214929 & 0.235971 & 425.60 \\
\hline SB16 & 385584 & 9214931 & 0.214435 & 468.35 \\
\hline SB17 & 385425 & 9214932 & 0.15492 & 648.27 \\
\hline SB17A & 385266 & 9215130 & 0.316759 & 524.13 \\
\hline SB18 & 385274 & 9214935 & 0.159994 & 627.71 \\
\hline
\end{tabular}




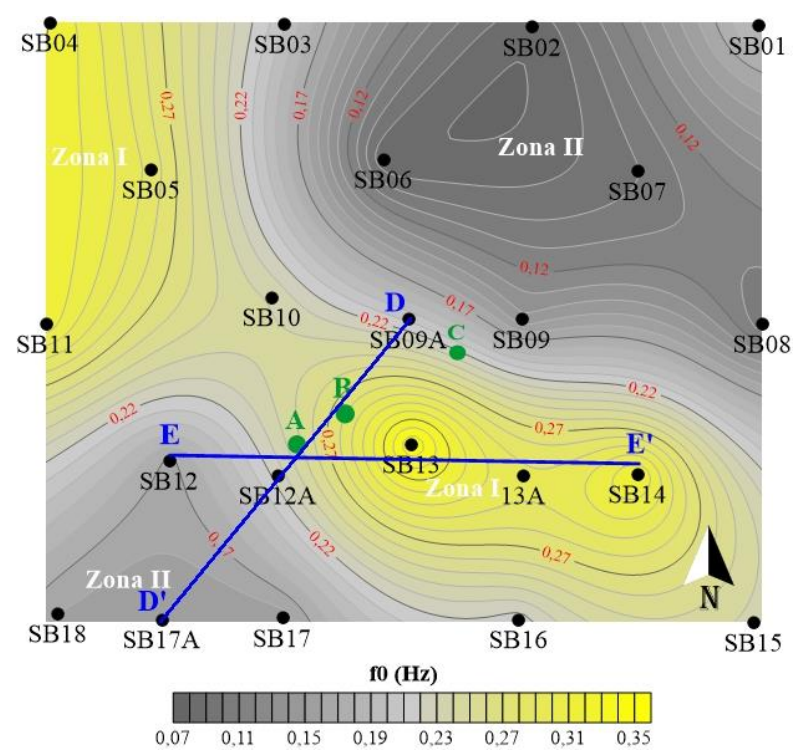

Fig. 6. Contour Map of Dominant Frequency (f0).

The variability of dominant frequency (f0) will impact directly to the thickness of sediment layer. If fo value decreasing then sediment thickness will increasing, and conversely [12]. At Fig 6, Zone I, the zone with yellow dominated tends to have f0 higher compared to Zone II that dominated with grey. On SB13 which has the highest dominant frequency, the sediment thickness was found to be $286.28 \mathrm{~m}$ by using equation (2) with $\mathrm{V}_{\mathrm{s}}$ value is 401.72 $\mathrm{m} / \mathrm{s}$ according to USGS data.

Table 2. Result of Acoustic Impedance (Z) Value Analysis.

\begin{tabular}{|c|c|c|c|c|}
\hline $\begin{array}{c}\text { Point } \\
\text { Name }\end{array}$ & $\begin{array}{c}\text { Elevation } \\
(\mathbf{m})\end{array}$ & $\begin{array}{c}\mathbf{V}_{\mathbf{p}} \\
(\mathbf{m} / \mathbf{s})\end{array}$ & $\begin{array}{c}\boldsymbol{\rho} \\
\left(\mathbf{k g} / \mathbf{m}^{\mathbf{3}}\right)\end{array}$ & $\begin{array}{c}\mathbf{Z} \\
\left(\mathbf{k g} / \mathbf{m}^{\mathbf{2}} \mathbf{s}\right)\end{array}$ \\
\hline SB09A & 662 & 477.6382 & 1400.044 & $668,714.7$ \\
\hline SB12A & 674 & 3593.513 & 1198.325 & $4,306,197$ \\
\hline SB17A & 680 & 249.1254 & 1213.466 & $302,305.3$ \\
\hline SB12 & 653 & 2368.91 & 1148.08 & $2,719,697$ \\
\hline SB13 & 672 & 1024.32 & 1221.881 & $1,251,598$ \\
\hline SB13A & 684 & 2450.635 & 1401.914 & $3,435,580$ \\
\hline SB14 & 690 & 2155.278 & 1206.352 & $2,600,023$ \\
\hline
\end{tabular}

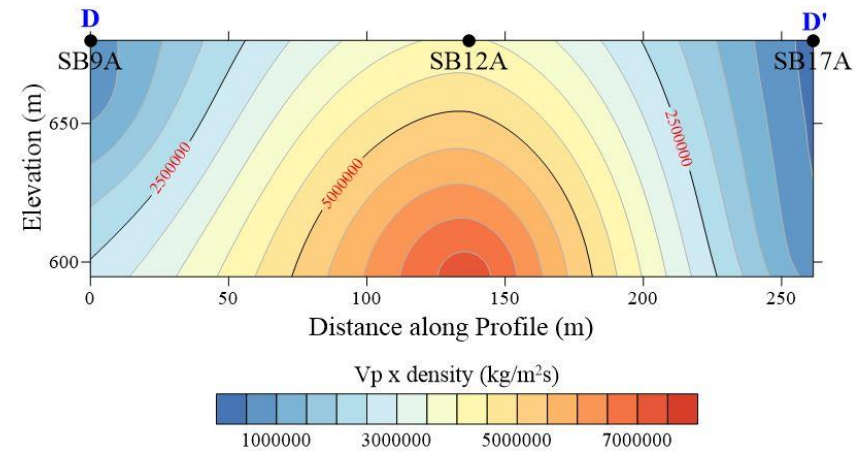

Fig. 7. Crossplot Acoustic Impedance (Z) from D-D'

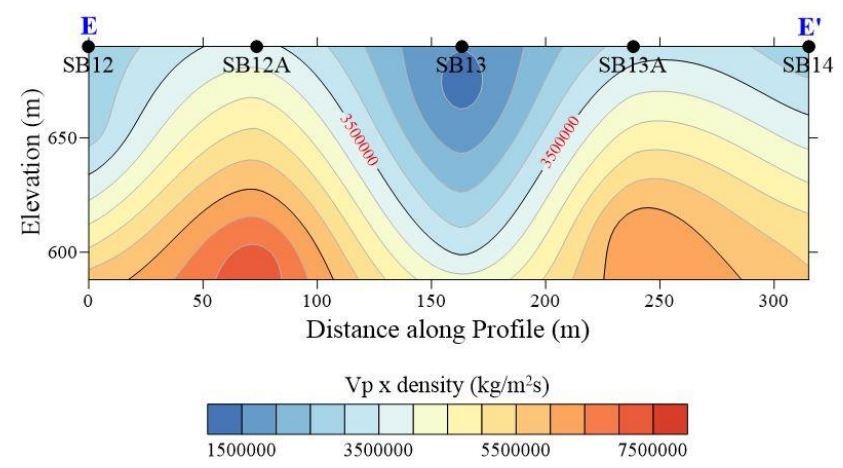

Fig. 8. Crossplot Acoustic Impedance (Z) from E-E'

After crossplot was done for $V_{p} \times \rho$ from SB09A to SB17A by drawing a line from D to D' and crossing three seepages points (Fig 6.), the highest $Z$ value was found on point SB12A. SB09A is a measurement point that very close to the seepages and also has $\mathrm{Z}$ value lower than SB12A (Fig 7.).

If seen by forward, the crossplot at fifth point (SB12, SB12A, SB13, SB13A, and SB14) by drawing a line EE', the lowest $Z$ value was found and it is located to SB13. According to Horsfall (2018), compactions of the rock depends on Acoustic Impedance (Z). If compactions of the rock has a high value, then porosity will be opposite. According to this law, SB13 has a low compactions but porosity is higher than SB12A and 13A.

\section{Conclusion}

According to HVSR curve analysis, at research site crossplot has been did around oil seepage points by crossing Zone I which showed dominant frequency with range of $0.20-0.35 \mathrm{~Hz}$ and Zone II has low dominant frequency in range of $0.08-0.19 \mathrm{~Hz}$.

SB13 separates a correlation between SB12A and SB13A against acoustic impedance $(Z)$ value. This separation gives a hypothesis, there is fractures in subsurface caused $\mathrm{Z}$ value is low and impact to porosity. This fractures predicted to be a migration of oil seepage with starts from SB09A which has lower $Z$ value and closer to point $\mathrm{C}$ with oil seepage really showed, and it is predicted towards to SB13.

The highest $V_{p} \times \rho$ is showed in SB12A with $4,306,197 \mathrm{~kg} / \mathrm{m}^{2} \mathrm{~s}$ and SB09A has acoustic impedance value $668,714.7 \mathrm{~kg} / \mathrm{m}^{2} \mathrm{~s}$, although SB17A has the lowest acoustic impedance however it has a great distance from seepage and not convince to be a migration path.

\section{References}

1. G. Zheng et al., Hydrocarbon seeps in petroliferous basins in China: A fi rst inventory, J. Asian Earth Sci., 151, 269-284 (2018).

2. M. C. Kennicutt II, Chapter 5 Oil and Gas Seeps in the Gulf of Mexico, Habitats and Biota of the Gulf of Mexico. Befor the Deepwater Horizon Oil Spill, 1, 275-358 (2017).

3. A. H. Satyana, Subvolcanic Hydrocarbon Prospectivity of Java: Opportunities and Challenges, 
in PROCEEDINGS, INDONESIAN PETROLEUM ASSOCIATION, 15 (2015).

4. A. H. Truesdell, Geochemical Evaluation of the Dieng Mountains, Central Java, (1971).

5. B. F. P. Masabanda, $A 3 D$ model of the Chachimbiro Geothermal System in Ecuador using PETREL, J. UNU-GTP, no. 34, 715-750 (2016).

6. A. S. Abdou, TEM and MT Resistivity surveying: Data acquisition, processing and $1 D$ inversion with an example from Hagongur Geothermal Field, MidIceland, J. UNU-GTP, no. 6, 1-38 (2015).

7. H. Okada, The Microtremor Survey Method, 12th ed. Tulsa: Society of Exploration Geophysicists, (2003)

8. M. Mirzaoglu and Ü. Dýkmen, Application of microtremors to seismic microzoning procedure, J. Balk. Geophys. Soc., 6, 3: 143-156 (2003).

9. M. Awanis, G. Yuliyanto, and U. Harmoko, Circular Configuration HVSR Response Spectra of Shallow Buried Rectangular Prism Model, 113-120 (2018).

10. U. Muksin, K. Bauer, and C. Haberland, Seismic Vp and Vp/Vs Structure of the Geothermal Area Around
Tarutung (North Sumatra, Indonesia) Derived from Local Earthquake Tomography, J. Volcanol. Geotherm. Res., 260, 27-42 (2013).

11. Y. Nakamura, On the $H / V$ Spectrum, 14th World Conf. Earthq. Eng., 14, 1-10 (2008).

12.P. Chemistra, W. Utama, and A. Syaeful B, Identifikasi Litologi Lapisan Sedimen Pada Mikrotremor HVSR, 7, 1: 77-80 (2018).

13. G. Yuliyanto, U. Harmoko, and R. D. Indriana, Identification of landslide area in Jabungan Village, Banyumanik, Semarang by using Microtremor method, Int. J. Recent Trends Eng. Res., 04, 05: 129137 (2018).

14. O. I. Horsfall, Impedance Attribute for Lithology Discrimination in HEK-Field of Niger Delta Basin of Nigeria, J. Sci. Eng. Res., 5, 9: 327-337 (2018).

15. P. A. Pameco and D. H. Amijaya, Pengaruh Struktur Geologi Terhadap Munculnya Rembesan Minyak Dan Gas Di Daerah Boto, Kecamatan Bancak, Kabupaten, Acad. Link., 8: 562-569 (2015). 